\title{
FAAP24 Gene
}

National Cancer Institute

\section{Source}

National Cancer Institute. FAAP24 Gene. NCI Thesaurus. Code C92470.

This gene is involved in both binding to and repair of DNA. 